Article

\title{
Mechanical, Thermal, and Moisture Buffering Properties of Novel Insulating Hemp-Lime Composite Building Materials
}

\author{
Yaser Abdellatef ${ }^{1,2}$, Mohammad Amil Khan ${ }^{3}$, Asif Khan ${ }^{3}\left[\right.$, Mehdi Iftekharul Alam ${ }^{3}(\mathbb{D}$ \\ and Miroslava Kavgic 1,3,* \\ 1 Civil Engineering Department, University of Ottawa, 161 Louis Pasteur, Ottawa, ON K1N 6N5, Canada; \\ yabde079@uottawa.ca \\ 2 Mechanical Power Department, Faculty of Engineering, Cairo University, Giza 12613, Egypt \\ 3 Civil Engineering Department, University of Manitoba, 15 Gillson St., Winnipeg, MB R3T 5V6, Canada; \\ mohammadamilkhan@gmail.com (M.A.K.); asifkhantupu@gmail.com (A.K.); \\ mehdi17uofm@gmail.com (M.I.A.) \\ * Correspondence: mkavgic@ottawa.ca
}

Received: 9 October 2020; Accepted: 4 November 2020; Published: 6 November 2020

check for updates

\begin{abstract}
Hempcrete is a sustainable biocomposite that can reduce buildings' embodied energy while improving energy performance and indoor environmental quality. This research aims to develop novel insulating hemp-lime composites using innovative binder mixes made of recycled and low-embodied energy pozzolans. The characterization of composites' mechanical and hygrothermal properties includes measuring compressive strength, splitting tensile strength, thermal conductivity, specific heat capacity, and moisture buffer capacities. This study also investigates the impact of sample densities and water content on compressive strength at different ages. The findings suggest that mixes with a 1:1 binder to hemp ratio and $300-400 \mathrm{~kg} / \mathrm{m}^{3}$ density have hygrothermal and mechanical properties suitable for insulating infill wall applications. Hence, compressive strengths, thermal conductivity, and specific heat capacity values range from 0.09 to $0.57 \mathrm{MPa}, 0.087$ to $0.10 \mathrm{~W} / \mathrm{m} \mathrm{K}$, and 1250 to $1557 \mathrm{~J} / \mathrm{kg} \mathrm{K}$, respectively. The average moisture buffer value for all hempcrete samples of $2.78\left(\mathrm{gm} / \mathrm{m}^{2} \mathrm{RH} \%\right)$ indicates excellent moisture buffering capacity. Recycled crushed brick pozzolan can enhance the hygrothermal performance of the hemp-lime composites. Thus, samples with 10\% crushed brick have the lowest thermal conductivity considering their density and the highest moisture buffer capacity. The new formulas of hydrated lime and crushed brick have mechanical properties comparable to metakaolin and hydraulic lime formulas.
\end{abstract}

Keywords: hemp-lime composites; mechanical properties; thermal properties; moisture buffering capacity; crushed brick; metakaolin; hydrated lime; hydraulic lime

\section{Introduction}

Hempcrete, made of the hemp plant's inner woody core mixed with a lime-based binder, is a promising lightweight biocomposite material that holds the potential to considerably improve energy and indoor environmental performance and sustainability of buildings [1,2]. Nevertheless, the utilization of hempcrete in the construction industry remains low, mainly due to the high variability of hemp-lime composites and lack of formulas that use widely available and locally sourced ingredients. For example, hempcrete's production cost and embodied energy could be considerably higher in Canada than in Europe due to imported materials [3]. The use of innovative binders and a better understanding of the material's performance are indispensable steps for addressing hempcrete underutilization. 
Previous studies have shown that hempcrete hygrothermal and mechanical properties depended on various factors. The binder to hemp ratio, compaction level, water content, and binder mix design have been considered to be critical [4-7]. For instance, an increase in the proportion of porous hemp hurd in hempcrete mixture reduced the dry density and the thermal conductivity $[6,8]$. In contrast, there was a positive correlation between density and thermal conductivity of the hempcrete $[9,10]$. Thus, studies have reported thermal conductivity in the range of $0.06-0.11 \mathrm{~W} / \mathrm{m} \mathrm{K}$ for hempcrete mixtures with dry densities ranging from 200 to $400 \mathrm{~kg} / \mathrm{m}^{3}$ and hemp/binder ratios of 1:1, 1:1.5, and 1:2 [11,12]. In comparison, hempcrete samples with higher dry density and hemp/binder ratio in the range of $450-800 \mathrm{~kg} / \mathrm{m}^{3}$ and 1:2-1:4, respectively, had higher thermal conductivity ranging from 0.12 to $0.18 \mathrm{~W} / \mathrm{m} \mathrm{K}[11,12]$. Previous findings have also indicated a negative correlation between hempcrete's density and moisture buffering capacity. For example, Latif et al. (2015) reported a moisture buffer value (MBV) of $3.47 \mathrm{gm} / \mathrm{m}^{2} \% \mathrm{RH}$ with a binder to hemp ratio of 1.2:1, and density of $290 \mathrm{~kg} / \mathrm{m}^{3}$ [13], while Collet et al. (2013) reported an MBV of $2.14 \mathrm{gm} / \mathrm{m}^{2} \% \mathrm{RH}$, with a binder to hemp ratio of 2:1, and density of $430 \mathrm{~kg} / \mathrm{m}^{3}$ [14].

Furthermore, an increase in water content tends to increase the thermal conductivity of the hempcrete mixes. Rahim et al. (2016) reported a rise in thermal conductivity of approximately $8 \%$ and $16 \%$ at $10^{\circ} \mathrm{C}$ and $40{ }^{\circ} \mathrm{C}$, respectively, due to an increase in the water content of $0.08 \mathrm{~kg} / \mathrm{kg}$ from the dry state [15]. The variation in specific heat capacity and thermal diffusivity under different humidity conditions was considerably less apparent than the variation in thermal conductivity [8]. Thus, specific heat capacity in the range of $1000-1590 \mathrm{~J} / \mathrm{kg} \mathrm{K}$ was reported for hempcrete with dry densities ranging from 381 to $627 \mathrm{~kg} / \mathrm{m}^{3}$ and hemp to binder ratio 1:2 [5,10]. Thermal diffusivity in the range of $1.48 \times 10^{-7} \mathrm{~m}^{2} / \mathrm{s}$ in the dry state to $0.98 \times 10^{-7} \mathrm{~m}^{2} / \mathrm{s}$ in the fully saturated condition and high specific heat capacity can provide a better thermal performance than suggested by hempcrete's thermal transmittance [16]. Moreover, hempcrete integration with other innovative materials can modify its thermal energy storage properties [17].

The typical value of the compressive strength of hempcrete mixes is between 0.2 and $1.15 \mathrm{MPa}$, whereas their flexural and splitting tensile strength values are in the range of $0.06-1.3 \mathrm{MPa}$ and 0.02-0.15 MPa, respectively $[9,18]$. A high content of hemp hurd in the design mix reduces the compressive and flexural strength of hemp-lime composites $[9,19]$. However, an increase in the density through compaction of the hempcrete can enhance its mechanical characteristics while reducing the binder's quantity, which is the major contributor to embodied carbon $[18,20,21]$. In this respect, Dinh (2014) reported approximately $15 \%$ higher compressive strength of a $556.0 \mathrm{~kg} / \mathrm{m}^{3}$ hempcrete sample than a $439.7 \mathrm{~kg} / \mathrm{m}^{3}$ sample with a compressive strength of $0.65 \pm 0.06 \mathrm{MPa}$ [6]. Likewise, the hempcrete mixes' splitting tensile strength increased with their density [18]. For instance, Elfordy et al. (2008) reported flexural strength in the range of $0.749-1.209 \mathrm{MPa}$, with a 2:1 binder to hemp ratio and a high-density range of $430-607 \mathrm{~kg} / \mathrm{m}^{3}$ [18].

Calcium hydroxide (i.e., hydrated lime) is particularly suitable for hemp-lime composites' production due to advantages such as breathability, high water vapour permeability, durability, mould resistance, and pest deterrence [22,23]. Furthermore, adding hydraulic lime and metakaolin can improve hempcrete's performance due to their fast setting, high reactivity, and lower embodied energy as compared with Portland cement [22,24]. Crushed brick is another promising pozzolan that belongs to an aluminosilicate group and is reactive towards lime, creating interfacial surface alkaline [25]. Therefore, utilizing reclaimed bricks from demolished buildings as pozzolanic lime mortars could extend their lifetime and reduce hempcrete's embodied energy.

This research study aims to develop innovative insulating hemp-lime composites made of recycled and locally sourced materials. To the best of the authors' knowledge, this is the first study that has used recycled crushed brick as a pozzolan to increase hemp-lime composites' availability and performance, while reducing their environmental impact. Unlike most previous studies that focused on hempcrete's mechanical, thermal, or moisture properties [10,23], this study experimentally estimated the mechanical strength (compressive and splitting tensile strength), thermal performance, and moisture 
regulation capabilities of eight hempcrete design mixes. Furthermore, in contrast to the existing studies that utilized a hemp/binder ratio of 1:2 or higher for wall formulas $[18,26]$, this research focused on maximizing the hemp hurd ratio to improve the thermal properties of the hempcrete mixtures. Therefore, a hemp/binder ratio of 1:1 with a targeted density of 300 to $400 \mathrm{~kg} / \mathrm{m}^{3}$ was applied to create an insulating "infill wall" formula. The effect of water content on the mechanical properties was also studied. Consequently, this research provides valuable information about insulating hemp-lime composites' critical performance required for material characterization that is likely to interest audiences in academia and industry, focusing on sustainable low-carbon composite building materials.

\section{Materials and Methods}

\subsection{Raw Materials}

Local hemp producer "Plains Hemp" provided the hemp hurd used as aggregate in this study. The bulk density of the hurd at room temperature of $20^{\circ} \mathrm{C}$ was $110 \pm 5 \mathrm{~kg} / \mathrm{m}^{3}$, whereas its dry density after oven drying at $105{ }^{\circ} \mathrm{C}$ for 24 hours was $101 \pm 2 \mathrm{~kg} / \mathrm{m}^{3}$. Sieve analysis was performed on an oven-dried batch of $100 \mathrm{~g}$, according to ASTM C136-06 [27], to determine the distribution of fine and coarse aggregates. Approximately $87 \%$ of the particles were less than $2.36 \mathrm{~mm}$, and $10 \%$ were between 2.36 and $6.3 \mathrm{~mm}$. The hydrated lime, metakaolin, and hydraulic lime, used in this study complied with ASTM C207-06 [28], ASTM C618-12 [29], and ASTM 1707-09 [30], respectively. Utilized recycled pozzolanic crushed brick had a density of $\sim 1355 \mathrm{~kg} / \mathrm{m}^{3}$, firing temperature between 600 and $900{ }^{\circ} \mathrm{C}$, and it was primarily composed of silicon dioxide (50-60\%) and aluminum oxide (20-30\%).

\subsection{Compositions of Hempcrete Samples}

This study focused on maximizing the hemp hurd ratio within the hempcrete mixture to improve its thermal properties while reducing its environmental impact. Hence, the hemp hurd to binder ratio used in the hempcrete sample preparation was $1: 1$ with a wall application density of 300 and $400 \mathrm{~kg} / \mathrm{m}^{3}$ [5,31]. Table 1 summarizes eight hempcrete design mixes with varying pozzolan concentrations and fifteen batches with varying water contents. The amount of water added to hemp-lime composites affects their physical properties. For instance, low water content may cause incomplete hydration and unreacted binder in powder form, leading to reduced compressive strength [23,32]. In contrast, high water content can result in higher density, leading to an increase in thermal conductivity, issues with a setting for the lime binder, and excessively long drying times for the hempcrete [6,33]. Furthermore, there is a lack of tests for measuring the workability of hemp-lime concretes, and experience is used to determine the appropriate water content. Therefore, we investigated different water contents that allowed the suitable workability of the developed hempcrete mixes. 
Table 1. Composition of hempcrete samples.

\begin{tabular}{|c|c|c|c|c|c|c|c|c|}
\hline \multirow[t]{2}{*}{ Design Mix } & \multirow[t]{2}{*}{ Name } & \multicolumn{6}{|c|}{$\begin{array}{c}\text { Mix Ratio by Mass } \\
\text { Hemp/Lime/Pozzolan/Water * }\end{array}$} & \multirow{2}{*}{$\begin{array}{c}\text { Hemp/Lime/Pozzolan/Water } \\
\text { (by Mass) }\end{array}$} \\
\hline & & $\mathbf{H}$ & $\mathbf{L}$ & CB & MK & NHL & Water & \\
\hline \multirow{3}{*}{$\begin{array}{c}\text { Hydrated } \\
\text { lime-crushed brick }\end{array}$} & LCB10 & 1 & 0.9 & 0.1 & - & - & 2.5 & $22 \% / 21 \% / 2 \% / 55 \%$ \\
\hline & LCB20 & 1 & 0.8 & 0.2 & - & - & 2.5 & $22 \% / 18 \% / 4 \% / 56 \%$ \\
\hline & LCB20A & 1 & 0.8 & 0.2 & - & - & 3 & $20 \% / 16 \% / / 4 \% / 60 \%$ \\
\hline \multirow{8}{*}{$\begin{array}{c}\text { Hydrated } \\
\text { lime-metakaolin }\end{array}$} & LMK10 & 1 & 0.9 & - & 0.1 & - & 2.6 & $22 \% / / 20 \% / 2 \% / 56 \%$ \\
\hline & LMK20 & 1 & 0.8 & - & 0.2 & - & 3 & $20 \% / 16 \% / 4 \% / 60 \%$ \\
\hline & LMK20A & 1 & 0.8 & - & 0.2 & - & 2.5 & $22 \% / 18 \% / 4 \% / 56 \%$ \\
\hline & LMK50 & 1 & 0.5 & - & 0.5 & - & 3 & $20 \% / 10 \% / 10 \% / 60 \%$ \\
\hline & LMK50A & 1 & 0.5 & - & 0.5 & - & 2.5 & $22 \% / 11 \% / 11 \% / 56 \%$ \\
\hline & LMK70 & 1 & 0.3 & - & 0.7 & - & 2.5 & $22 \% / 7 \% / 15 \% / 56 \%$ \\
\hline & LMK70A & 1 & 0.3 & - & 0.7 & - & 2.75 & $21 \% / 6 \% / 15 \% / 58 \%$ \\
\hline & LMK70B & 1 & 0.3 & - & 0.7 & - & 3 & $20 \% / 6 \% / 14 \% / 60 \%$ \\
\hline \multirow{4}{*}{$\begin{array}{c}\text { Hydrated } \\
\text { lime-natural } \\
\text { hydraulic lime }\end{array}$} & LNHL50 & 1 & 0.5 & - & - & 0.5 & 2.5 & $22 \% / 11 \% / 11 \% / 56 \%$ \\
\hline & LNHL50A & 1 & 0.5 & - & - & 0.5 & 3 & $20 \% / 10 \% / 10 \% / 60 \%$ \\
\hline & LNHL70 & 1 & 0.3 & - & - & 0.7 & 2.5 & $22 \% / 7 \% / 15 \% / 56 \%$ \\
\hline & LNHL70A & 1 & 0.3 & - & - & 0.7 & 3 & $20 \% / 6 \% / 14 \% / 60 \%$ \\
\hline
\end{tabular}

${ }^{*} \mathrm{H}$, hemp hurd; L, hydrated lime; MK, metakaolin; NHL, natural hydraulic lime; $\mathrm{CB}$, crushed brick.

\subsection{Mixing, Moulding, and Curing}

Mixing binders and water to create a slurry was the first step in creating hempcrete samples. Then, hemp hurd was added to the slurry and blended in an industrial mixer for approximately $5 \mathrm{~min}$ until a uniform mixture was obtained. For the thermal properties' tests and moisture buffering tests, rectangular wooden moulds ( $26 \mathrm{~cm}$ wide $\times 26 \mathrm{~cm}$ long $\times 5.5 \mathrm{~cm}$ high) were filled with the mixture and tamped until reaching the desired wet density. The cylindrical moulds $(10 \mathrm{~cm}$ diameter $\times 20 \mathrm{~cm}$ long) for compression tests were prepared according to ASTM C39/C39M-12 [34]. Furthermore, for splitting tensile tests, the cylindrical moulds $(15 \mathrm{~cm}$ diameter $\times 30 \mathrm{~cm}$ long) were produced by following ASTM C496/C496M-17 [35]. Then, a one-quarter portion of the mould at a time was filled with the mixture and tamped until the desired wet density was reached (i.e., $750-800 \mathrm{~kg} / \mathrm{m}^{3}$ ). The samples were demolded after seven days and cured at room temperature of $22 \pm 1{ }^{\circ} \mathrm{C}$, with $\mathrm{RH} \sim 50 \%$ for another 21-28 days until they reached a constant mass. In total, approximately 220 samples were tested for their mechanical, thermal, and moisture buffering properties.

\subsection{Experimental Tests}

\subsubsection{Mechanical Tests}

The compression and splitting tensile tests were performed by following the ASTM D4832 [36] and ASTM C496 [35] standards, respectively. The compressive strength was measured after 28, 60, and 90 days, while splitting tensile strength was measured after 90 days. The load was applied continuously without any shock at a $5 \mathrm{~mm} / \mathrm{min}$ rate and run for approximately $4-5 \mathrm{~min}$ per specimen. The mode of failure was determined by the drop observed in the load-displacement curve after the initial increase. For each design mix and age, we tested four samples and calculated compressive strength as their average. Data obtained from the compression test were used to calculate Young's modulus, according to ASTM C469 [37]. For splitting tensile tests, we tested two samples for each design mix and computed their averages.

\subsubsection{Thermal Tests}

A FOX 314 Heat Flow Meter Apparatus (HFMA) was used for thermal conductivity and specific heat capacity measurements of the hempcrete samples, according to ASTM C518 [38] and ASTM 
C1784 [39] standards, respectively. Thermal tests included "wet" samples at room temperature of $22 \pm 1{ }^{\circ} \mathrm{C}$, with $\mathrm{RH} \sim 50 \%$ and "dry" samples, oven-dried at $100 \pm 5^{\circ} \mathrm{C}$ until a constant mass was reached (i.e., changes in weight readings of less than $0.1 \%$ ). The HFMA created steady one-dimensional heat flux through the specimens by setting both plates at constant but different temperatures with an accuracy of $\pm 0.03{ }^{\circ} \mathrm{C}$. The HFMA applied Fourier's law of heat conduction to obtain hempcrete's thermal conductivity with an accuracy of approximately $1 \%$ at a specific mean temperature of the plates. Additionally, we calibrated the HFMA to convert transducers' voltage signals to heat fluxes using NIST 1450b SRM (Standard Reference Material of the National Institute of Standards and Technology) [40]. The HFMA was modified to measure hempcrete samples' specific heat capacity by first maintaining both plates at the equal temperature until reaching a steady-state condition, then changing the plates' temperatures by the same step, and holding them until reaching a new steady-state condition. By assuming transient heat conduction in a finite body for a significant time, the specific heat capacity was determined at each temperature step using Equation (1), according to Tleoubaev and Brzezinski (2007) [41]:

$$
C_{p}=\frac{k}{\rho L^{2} \pi^{-2}\left(\frac{\Delta \ln \left(Q_{i}\right)}{\Delta t}\right)}
$$

where $L$ is sample thickness $(\mathrm{m}), \rho$ is density $\left(\mathrm{kg} / \mathrm{m}^{3}\right), k$ is thermal conductivity $(\mathrm{W} / \mathrm{m} \mathrm{K})$, and $\left(\Delta \ln Q_{i} \Delta t\right)$ is the slope of the curve of the natural logarithm of HFMA output values versus time.

The uncertainty in specific heat capacity was calculated at each temperature setpoint to be approximately $\pm 2.5 \%$, using Equation (2):

$$
\mathrm{U}_{C_{p}}=\sqrt{\left(\frac{\partial C_{p}}{\partial k} U_{k}\right)^{2}+\left(\frac{\partial C_{p}}{\partial \rho} U_{\rho}\right)^{2}+\left(\frac{\partial C_{p}}{\partial L} U_{L}\right)^{2}+\left(\frac{\partial C_{p}}{\partial(\text { slope })} U_{\text {slope }}\right)^{2}}
$$

where $U_{k}$ is uncertainty in thermal conductivity $( \pm 1 \%), U_{\rho}$ is uncertainty in density $( \pm 1.75 \%)$, $U_{L}$ is uncertainty in thickness $( \pm 0.025 \mathrm{~mm})$, and $U_{\text {slope }}$ is uncertainty in slope $( \pm 0.4 \%$ with $95 \%$ confidence level).

Furthermore, the hempcrete samples' thermal diffusivity was calculated using HFMA measurements of thermal conductivity and specific heat capacity, as shown in Equation (3):

$$
\alpha=\frac{k}{\rho C_{p}}
$$

where $k$ is the thermal conductivity $(\mathrm{W} / \mathrm{m} \mathrm{K}), \rho$ is density $\left(\mathrm{kg} / \mathrm{m}^{3}\right)$, and $C_{p}$ is the specific heat capacity $(\mathrm{J} / \mathrm{kg} \mathrm{K})$.

\subsubsection{Moisture Buffering Capacity Tests}

According to the NORDTEST protocol [42], the measurements of hempcrete's moisture buffer capacity included sealing all specimens' sides except the upper surface $(26 \mathrm{~cm} \times 26 \mathrm{~cm})$, exposed to humidity cycles. The air temperature in the climate chamber was kept constant at $23 \pm 1{ }^{\circ} \mathrm{C}$, while the relative humidity (RH) was kept constant at $75 \pm 2 \%$ for 8 hours and $33 \pm 2 \%$ for 16 hours. Due to the importance of the initial conditions of the samples' moisture contents [43,44], their effect was studied using two different initial states, high moisture content $(75 \% \mathrm{RH})$ and low moisture content $(33 \% \mathrm{RH})$. The mass of each sample mass was measured using an electronic scale with an accuracy $\pm 0.01 \mathrm{gm}$ to monitor the mass change during the uptake and release phases. The humidity cycles were repeated until the steady-state condition was reached, and the mass change in the cycles' uptake and release phases was less than 5\% [42]. The moisture buffer value (MBV) was calculated as the average of the last three steady cycles, using Equation (4): 


$$
M B V=\frac{\Delta m}{A(\Delta R H \%)}
$$

where $\Delta m$ in the mass change (gm), A is the exposed surface area $\left(\mathrm{m}^{2}\right)$, and $\Delta R H \%$ is the difference between the high and low relative humidity.

\section{Results}

\subsection{Density Results}

Figure 1 shows that approximately $91 \%$ of the specimens are within the density range from 300 to $350 \mathrm{~kg} / \mathrm{m}^{3}$. The average density and the amount of variation are $323 \mathrm{~kg} / \mathrm{m}^{3}$ and $12 \mathrm{~kg} / \mathrm{m}^{3}$, respectively, the minimum is $290 \mathrm{~kg} / \mathrm{m}^{3}$, and the maximum is $372 \mathrm{~kg} / \mathrm{m}^{3}$. These results suggest consistency between the average densities of hempcrete samples produced in this study. Furthermore, Table 2 summarizes descriptive statistics of compression, tensile, and thermal samples. The samples prepared for compressive tests have the highest average density $\left(\sim 340 \mathrm{~kg} / \mathrm{m}^{3}\right)$, followed by the splitting tensile samples $\left(\sim 324 \mathrm{~kg} / \mathrm{m}^{3}\right)$, and thermal samples $\left(\sim 315 \mathrm{~kg} / \mathrm{m}^{3}\right)$. Similarly, the specimens created for the compressive tests exhibit the highest standard deviation of $17.2 \mathrm{~kg} / \mathrm{m}^{3}(\sim 5 \%)$, followed by tensile specimens with a standard deviation of $12.1 \mathrm{~kg} / \mathrm{m}^{3}(\sim 3.8 \%)$. Thermal samples share similar variations in density $(\sim 2.7 \%)$, for both wet and dry tests.

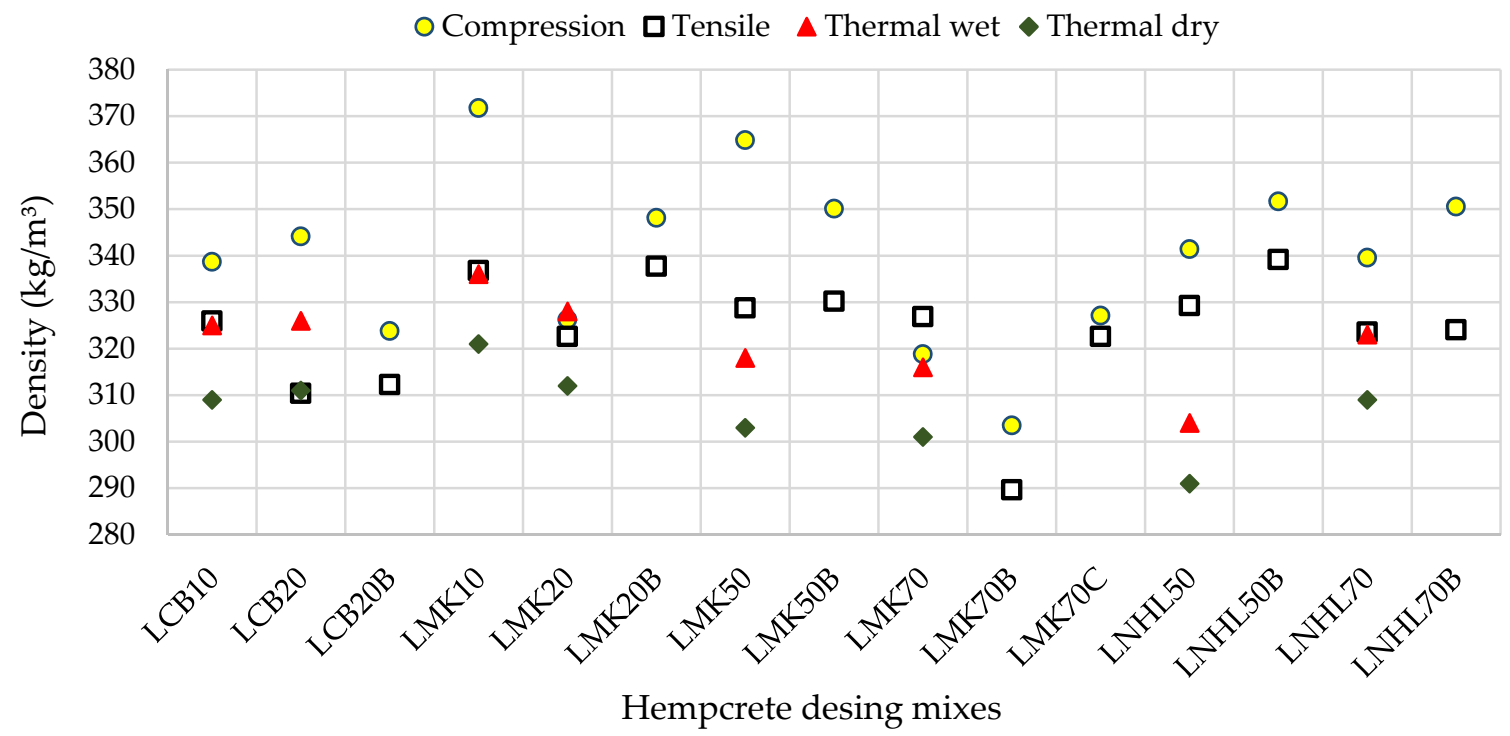

Figure 1. Average densities of all hempcrete samples.

Table 2. Descriptive statistics of samples.

\begin{tabular}{ccccc}
\hline Density $\mathbf{( k g} / \mathbf{m}^{\mathbf{3}}$ ) & Compression & Splitting Tensile & Thermal Wet & Thermal Dry \\
\hline Minimum & 304 & 290 & 304 & 291 \\
Average * & $340 \pm 9$ & $324 \pm 6$ & $322 \pm 6$ & $307 \pm 6$ \\
Maximum & 372 & 339 & 336 & 321 \\
Standard deviation & 17.2 & 12.1 & 8.9 & 8.3 \\
\hline
\end{tabular}

${ }^{*}$ Confidence intervals (for $95 \%$ confidence level.).

\subsection{Compression and Splitting Tensile Test Results}

Table 3 summarizes the average compressive strength, splitting tensile strength, modulus of elasticity, and hempcrete samples' densities. The samples' average compressive strength is $0.28 \mathrm{MPa}$, with a standard deviation of $0.098 \mathrm{MPa}(35 \%)$, and it ranges from $0.11 \mathrm{MPa}$ (LMK70B) to $0.47 \mathrm{MPa}$ (LMK50B). Due to less variation in the samples' density for splitting tensile tests than compressive tests 
(see Table 2), tensile strength dispersion is slightly lower than compression values. Thus, the average splitting tensile strength of all samples is $0.024 \mathrm{MPa}$, with a standard deviation of $0.0065 \mathrm{MPa}(27 \%)$, and it ranges from $0.0101 \mathrm{MPa}$ to $0.0348 \mathrm{MPa}$.

Table 3. Average compression strength, tensile strength, Young's modulus, density, and water content.

\begin{tabular}{|c|c|c|c|c|c|c|}
\hline Name & Water (kg) & $\begin{array}{c}\text { Density } \\
\left(\mathrm{CT}^{1}\right)\left(\mathrm{kg} / \mathrm{m}^{3}\right)\end{array}$ & $\begin{array}{l}\text { Compressive } \\
\text { Strength (MPa) }\end{array}$ & $\begin{array}{c}\mathrm{E} \\
(\mathrm{MPa})\end{array}$ & $\begin{array}{l}\text { Density } \\
\left(\mathrm{STT}^{2}\right) \\
\left(\mathrm{kg} / \mathrm{m}^{3}\right)\end{array}$ & $\begin{array}{l}\text { Splitting Tensile } \\
\text { Strength (MPa) }\end{array}$ \\
\hline LCB10 & 2.5 & 339 & 0.32 & 10.42 & 326 & 0.0244 \\
\hline LCB20 & 2.5 & 344 & 0.19 & 6.38 & 310 & 0.0219 \\
\hline LCB20B & 3 & 324 & 0.26 & 3.16 & 312 & 0.0223 \\
\hline LMK10 & 2.6 & 372 & 0.36 & 10.84 & 329 & 0.0219 \\
\hline LMK20 & 2.5 & 326 & 0.21 & 7.20 & 330 & 0.0270 \\
\hline LMK20B & 3 & 348 & 0.28 & 9.00 & 323 & 0.0222 \\
\hline LMK50 & 2.5 & 365 & 0.33 & 8.05 & 338 & 0.0307 \\
\hline LMK50B & 3 & 350 & 0.47 & 8.31 & 337 & 0.0342 \\
\hline LMK70 & 2.5 & 319 & 0.14 & 7.64 & 327 & 0.0160 \\
\hline LMK70B & 2.75 & 304 & 0.11 & 4.27 & 290 & 0.0101 \\
\hline LMK70C & 3 & 327 & 0.18 & 4.00 & 323 & 0.0183 \\
\hline LNHL50 & 2.5 & 341 & 0.26 & 9.01 & 329 & 0.0307 \\
\hline LNHL50B & 3 & 352 & 0.42 & 5.21 & 339 & 0.0348 \\
\hline LNHL70 & 2.5 & 340 & 0.30 & 10.22 & 324 & 0.0260 \\
\hline LNHL70B & 3 & 351 & 0.38 & 8.22 & 324 & 0.0229 \\
\hline
\end{tabular}

${ }^{1}$ Compression test; ${ }^{2}$ splitting tensile test.

Overall, an increase in hempcrete density leads to a rise in its compressive and tensile strengths. These findings are consistent with the results of previous studies [18]. Thus, the hempcrete samples of $350 \mathrm{~kg} / \mathrm{m}^{3}$ and denser have an average compressive strength of $0.33 \mathrm{MPa}$ and higher. In contrast, the specimens with the lowest density, including LMK70B $\left(303.5 \mathrm{~kg} / \mathrm{m}^{3}\right), \operatorname{LMK} 70\left(318.8 \mathrm{~kg} / \mathrm{m}^{3}\right)$, and LMK70C $\left(327.1 \mathrm{~kg} / \mathrm{m}^{3}\right)$, have the lowest average compressive strength ranging from $0.11 \mathrm{MPa}$ to $0.18 \mathrm{MPa}$. Similarly, the highest splitting tensile strength of $0.0348 \mathrm{MPa}$ has the LNHL50B sample with the highest density of $339.15 \mathrm{~kg} / \mathrm{m}^{3}$, whereas the least dense LMK70B $\left(\sim 289 \mathrm{~kg} / \mathrm{m}^{3}\right)$ has the lowest splitting tensile strength of $0.01 \mathrm{MPa}$. Nevertheless, the two samples with the highest compressive strengths, LMK50B, and LNHL50B, are not the most compacted hempcrete samples. These results suggest that water content, binder type, and content also significantly impact hemp-lime concretes' mechanical properties.

Hence, on the one hand, an increase in the water content increases the compressive strength, even of the samples with lower densities. For example, the LCB20 sample with $2.5 \mathrm{~kg}$ of water and $344.1 \mathrm{~kg} / \mathrm{m}^{3}$ density has a compressive strength of $0.19 \mathrm{MPa}$, while the LCB20B sample with $3 \mathrm{~kg}$ of water and $323.8 \mathrm{~kg} / \mathrm{m}^{3}$ density has a compressive strength of $0.26 \mathrm{MPa}$. Metakaolin samples with percentages above $20 \%$, and all LNHL samples exhibit a similar trend. On the other hand, the design mixes with smaller water content (i.e., 2.5:1 water to hemp ratio) show inferior compressive and tensile strengths compared with other hempcrete specimens. These results echo Walker and Pavia's (2014) observations regarding hemp's high suction ability that undermined the binder's hydration and adversely affected the strength of hemp-lime composites [23]. The sample produced from LMK70 (lime 30\% and metakaolin 70\%) show the highest amount of unreacted binder and has the lowest compressive and splitting tensile strengths. The LNHL50 sample, cast in two batches, shows an average compressive strength of only $0.26 \mathrm{MPa}$ using a water to hemp ratio of 2.5:1 and approximately $60 \%$ higher (0.42 MPa) using a water to hemp ratio of 3:1. Similarly, the LNHL70 sample prepared with a water to hemp ratio of 2.5:1 exhibits an average compressive strength of $0.30 \mathrm{MPa}$, which is around $21 \%$ below the compressive strength of the sample with water to hemp ratio of 3:1.

Furthermore, an increase in the percent of metakaolin and crushed brick above a certain amount reduces the compressive strength of hempcrete. This effect is most pronounced in the LMK samples 
in which compressive strength decreases from $62 \%$ to $76 \%$, with an increase in the percent share of metakaolin from $50 \%$ to $70 \%$. Similarly, an increase in the percent share of metakaolin and NHL hurts the tensile strength of hempcrete. Thus, an increase in the percentage of metakaolin from $50 \%$ to $70 \%$ results in a $16 \%$ to $62 \%$ decrease in hempcrete tensile strength, depending on the batch. An increase in hydraulic lime from $50 \%$ to $70 \%$ decreases the tensile strength for approximately $15 \%$ to $34 \%$, whereas an increase in the crushed brick from $10 \%$ to $20 \%$ exhibits the lowest decreases in the tensile strength of $8 \%$ to $10 \%$. On the one hand, these results support Dinh (2014) findings regarding the adverse effect of an increase in metakaolin share above $70 \%$ on the compressive strength of hempcrete [6]. On the other hand, Eires et al. (2006) stated that $75 \%$ of metakaolin and $25 \%$ of lime were the best binder mix [45]. However, they also reported that this design mix required higher curing temperatures to increase strength gain.

As presented in Table 3, the modulus of elasticity shows a wide variation between design mixes and a weak relationship with the samples' density. Thus, Young's modulus ranges from 3.16 to $10.84 \mathrm{MPa}$, and its average value of all samples is $7.46 \mathrm{MPa}$, with a standard deviation of $2.327 \mathrm{MPa}$ $(31 \%)$. Increasing the metakaolin and crushed brick content reduces Young's modulus, whereas increasing hydraulic lime does not have the same effect. The LCB20 sample shows the lowest value of Young's modulus (3.16 MPa), followed by LMK70C (4.00 MPa). In contrast, the LMK10 specimen has the highest Young's modulus (10.84 MPa), followed by LCB10 (10.42 MPa) and LNHL70 (10.22 MPa).

Figure 2 compares densities and compressive strengths on the 28th, 60th, and 90th day among the developed samples and against previous studies with similar hempcrete densities [18,26]. The results show that specimens, on the one hand, with the lowest densities of approximately $303 \mathrm{~kg} / \mathrm{m}^{3}$ and $318 \mathrm{~kg} / \mathrm{m}^{3}$ have $30-50 \%$ lower compressive strength than the results in the literature $[18,26]$. The likely reason is a higher content of binder used in these studies. In this regard, Elfordy et al. (2008) [18] and Williams et al. (2017) [26] used a 2:1 and 2.25:1, respectively, binder to hemp ratio. On the other hand, samples with a density of approximately $340 \mathrm{~kg} / \mathrm{m}^{3}$ and above have compressive strength comparable with Elfordy et al. (2008) [18] and Williams et al. (2017) [26]. Some studies have also differentiated between testing in the perpendicular $(\perp)$ and the parallel $(\|)$ direction to the direction of compaction. In this respect, Williams et al. (2017) reported slightly higher compressive strengths of the samples with similar density tested in perpendicular than parallel direction (see Figure 2) [26]. In this research, the compaction and testing directions (i.e., perpendicular or parallel) were designed to present the worst-case scenario for mechanical properties. Therefore, parallel testing to the compaction direction might be another reason for differences between our results and values reported by Williams et al. (2017) [26].

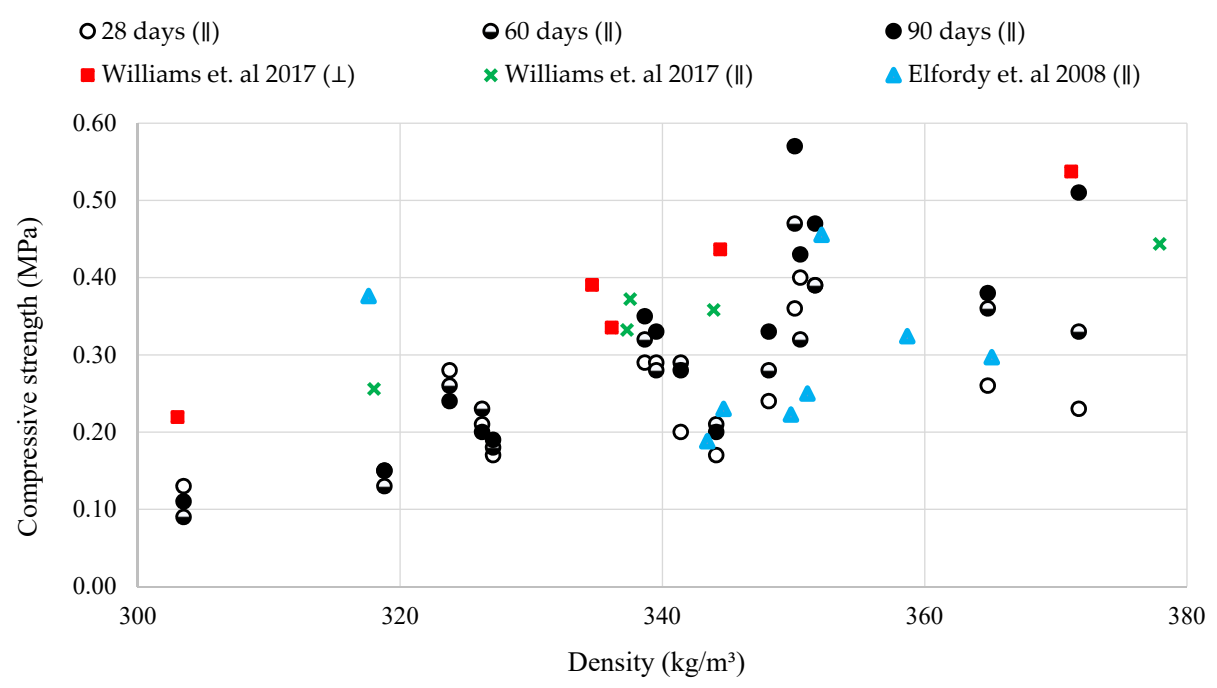

Figure 2. Comparison of density, compressive strength, and age. 


\subsection{Thermal Properties Results}

Table 4 presents the dry and wet hempcrete samples' thermal properties, including their density, thermal conductivity, specific heat capacity, and thermal diffusivity. The wet hempcrete samples have higher density, thermal conductivity, and specific heat capacity than their dry counterparts due to the higher moisture content. Thus, the wet density ranges from $304 \mathrm{~kg} / \mathrm{m}^{3}$ to $336 \mathrm{~kg} / \mathrm{m}^{3}$, and the average is $322 \mathrm{~kg} / \mathrm{m}^{3}$. In comparison, the dry density is approximately $4.5 \%$ lower, ranging from $291 \mathrm{~kg} / \mathrm{m}^{3}$ to $321 \mathrm{~kg} / \mathrm{m}^{3}$ with an average of $307 \mathrm{~kg} / \mathrm{m}^{3}$. The thermal conductivities of wet and dry samples vary from 0.091 to $0.101 \mathrm{~W} / \mathrm{m} \mathrm{K}$ and from 0.087 to $0.096 \mathrm{~W} / \mathrm{m} \mathrm{K}$, with averages of 0.096 and $0.0913 \mathrm{~W} / \mathrm{m} \mathrm{K}$, respectively. Furthermore, the specific heat capacities of wet and dry samples range from 1398 to $1557 \mathrm{~J} / \mathrm{kg} \mathrm{K}$ and from 1250 to $1421 \mathrm{~J} / \mathrm{kg} \mathrm{K}$, with averages of 1508 and $1365 \mathrm{~J} / \mathrm{kg} \mathrm{K}$, respectively. These results range from specific heat capacity values reported in the literature, between 1000 and $1560 \mathrm{~J} / \mathrm{kg} \mathrm{K}[5,46]$.

Table 4. Thermal properties of the hempcrete samples.

\begin{tabular}{|c|c|c|c|c|c|}
\hline Sample & State & $\begin{array}{l}\text { Density } \\
\left(\mathrm{kg} / \mathrm{m}^{3}\right)\end{array}$ & $\begin{array}{c}\text { Thermal } \\
\text { Conductivity } \\
(\mathrm{W} / \mathrm{m} \mathrm{K})\end{array}$ & $\begin{array}{c}\text { Specific Heat } \\
\text { Capacity (J/kg K) }\end{array}$ & $\begin{array}{c}\text { Thermal } \\
\text { Diffusivity } \\
\left(\mathrm{m}^{2} / \mathrm{s}\right) \times 10^{-7}\end{array}$ \\
\hline \multirow{2}{*}{ LCB10 } & wet & 325 & 0.0962 & 1504 & 1.968 \\
\hline & dry & 309 & 0.0921 & 1350 & 2.209 \\
\hline \multirow{2}{*}{ LCB20 } & wet & 326 & 0.0943 & 1398 & 2.069 \\
\hline & dry & 311 & 0.0902 & 1250 & 2.321 \\
\hline \multirow{2}{*}{ LMK10 } & wet & 336 & 0.1007 & 1536 & 1.951 \\
\hline & dry & 321 & 0.0959 & 1397 & 2.140 \\
\hline \multirow{2}{*}{ LMK20 } & wet & 328 & 0.0981 & 1530 & 1.955 \\
\hline & dry & 312 & 0.0937 & 1385 & 2.169 \\
\hline \multirow{2}{*}{ LMK50 } & wet & 318 & 0.0955 & 1523 & 1.972 \\
\hline & dry & 303 & 0.0910 & 1379 & 2.178 \\
\hline \multirow{2}{*}{ LMK70 } & wet & 316 & 0.0941 & 1498 & 1.988 \\
\hline & dry & 301 & 0.0898 & 1352 & 2.206 \\
\hline \multirow{2}{*}{ LNHL50 } & wet & 304 & 0.0907 & 1520 & 1.962 \\
\hline & dry & 291 & 0.0868 & 1383 & 2.156 \\
\hline \multirow{2}{*}{ LNHL70 } & wet & 323 & 0.0952 & 1557 & 1.893 \\
\hline & dry & 309 & 0.0912 & 1421 & 2.076 \\
\hline
\end{tabular}

In addition, the wet samples' thermal diffusivity is lower as compared with their dry counterparts. In this respect, thermal diffusivity of the wet samples ranges from 1.893 to $2.069\left(\mathrm{~m}^{2} / \mathrm{s}\right) \times 10^{-7}$, whereas dry specimens range from 2.076 to $2.321\left(\mathrm{~m}^{2} / \mathrm{s}\right) \times 10^{-7}$, with averages of $1.970\left(\mathrm{~m}^{2} / \mathrm{s}\right) \times 10^{-7}$ and $2.182\left(\mathrm{~m}^{2} / \mathrm{s}\right) \times 10^{-7}$, respectively. These findings indicate that, in the wet state, the total increase in heat storage $\left(\rho \times c_{p}\right)$ is higher than the increase in thermal conductivity. Thus, the wet state's thermal diffusivity $\left(\frac{k}{\rho C_{p}}\right)$ is lower than that of the dry state (i.e., have higher thermal inertia than the dry samples.) Our results are slightly higher than the range of thermal diffusivity values reported in the literature, between 0.98 and $1.68\left(\mathrm{~m}^{2} / \mathrm{s}\right) \times 10^{-7}$ [5,47]. A possible explanation might be the higher density values that previous studies used to calculate thermal diffusivity.

The results presented in Table 4 indicate that the hempcrete samples with crushed brick have the lowest thermal conductivity and specific heat capacity, considering their density and the highest thermal diffusivity. For example, the average density, thermal conductivity, specific heat capacity, and thermal diffusivity of all hempcrete samples with crushed brick (wet and dry) are approximately $318 \mathrm{~kg} / \mathrm{m}^{3}, 0.93 \mathrm{~W} / \mathrm{m} \mathrm{K}, 1376 \mathrm{~J} / \mathrm{kg} \mathrm{K}$, and $2.142\left(\mathrm{~m}^{2} / \mathrm{s}\right) \times 10^{-7}$, respectively. In comparison, the metakaolin hempcrete samples have a similar average density $\left(\sim 317 \mathrm{~kg} / \mathrm{m}^{3}\right)$ but higher thermal conductivity $(\sim 0.95 \mathrm{~W} / \mathrm{m} \mathrm{K})$ and specific heat capacity $(\sim 1450 \mathrm{~J} / \mathrm{kg} \mathrm{K})$. The LNHL hempcrete samples have the lowest average density of approximately $307 \mathrm{~kg} / \mathrm{m}^{3}$, and therefore the lowest thermal conductivity of 
$0.091 \mathrm{~W} / \mathrm{m} \mathrm{K}$. Nevertheless, they have the highest average specific heat capacity of $1470 \mathrm{~J} / \mathrm{kg} \mathrm{K}$, and the lowest thermal diffusivity of $2.020\left(\mathrm{~m}^{2} / \mathrm{s}\right) \times 10^{-7}$.

Figure 3 illustrates the relation between thermal conductivity and density in the dry and wet states for all design mixes. Similar to previous studies $[9,26]$, both the dry and wet samples show a positive linear relationship between the samples' conductivities and densities with $\mathrm{R}^{2}$ values of 0.907. Thus, the LNHL50 samples with the lowest dry and wet densities of 291 and $304 \mathrm{~kg} / \mathrm{m}^{3}$ have the lowest thermal conductivity of approximately 0.087 and $0.90 \mathrm{~W} / \mathrm{m} \mathrm{K}$, respectively. In contrast, the LMK10 samples with the highest dry and wet densities of 321 and $336 \mathrm{~kg} / \mathrm{m}^{3}$ have the highest thermal conductivity of approximately 0.096 and $0.1 \mathrm{~W} / \mathrm{m} \mathrm{K}$, respectively.

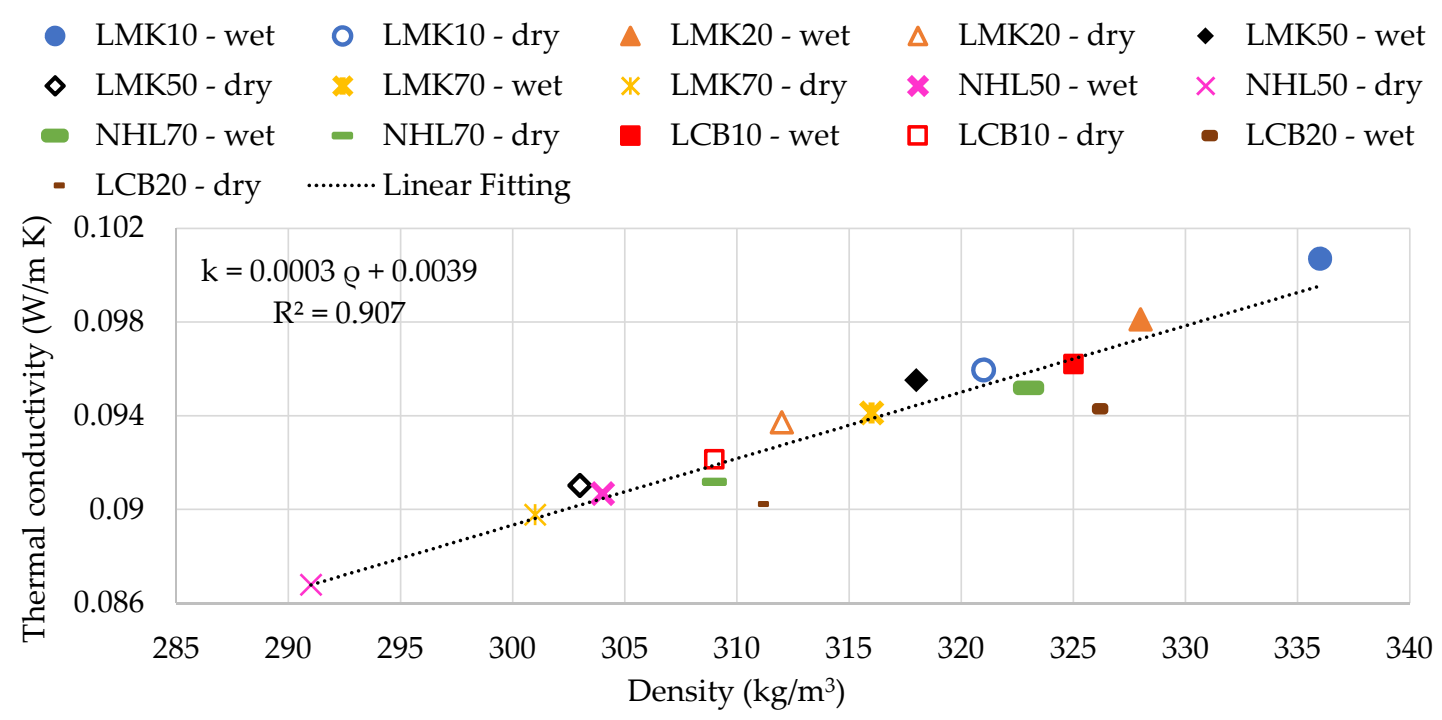

Figure 3. Thermal conductivity as a function of density.

Figure 4 compares the experimental average thermal conductivities of hempcrete samples against the results of previous studies. The results show that the thermal conductivities and their increase with density are comparable to the values reported by previous studies for the specimens with similar densities. Furthermore, some studies differentiate between testing in the perpendicular $(\perp)$ and parallel $(\|)$ direction (i.e., heat flux direction) to the compaction of the samples. In this respect, Williams et al. (2017) [26] and Nguyen et al. (2010) [48] reported higher thermal conductivity of the samples with similar density tested in perpendicular than parallel direction (see Figure 4). Moreover, Nguyen et al. (2010) [48] reported a higher difference between the parallel and perpendicular conductivities than Williams et al. (2017) [26]. The likely reason is the higher density range of the samples in the first study compared with that of the second study. In this research, the compaction and testing directions (i.e., perpendicular or parallel) represent the worst-case scenario for the thermal properties. In this respect, the HFMA created heat flux across the samples, perpendicular to the compaction direction. Thus, our results show a good match with experiments conducted in the perpendicular direction [26], and a more significant discrepancy with those performed in the parallel orientation [26]. 


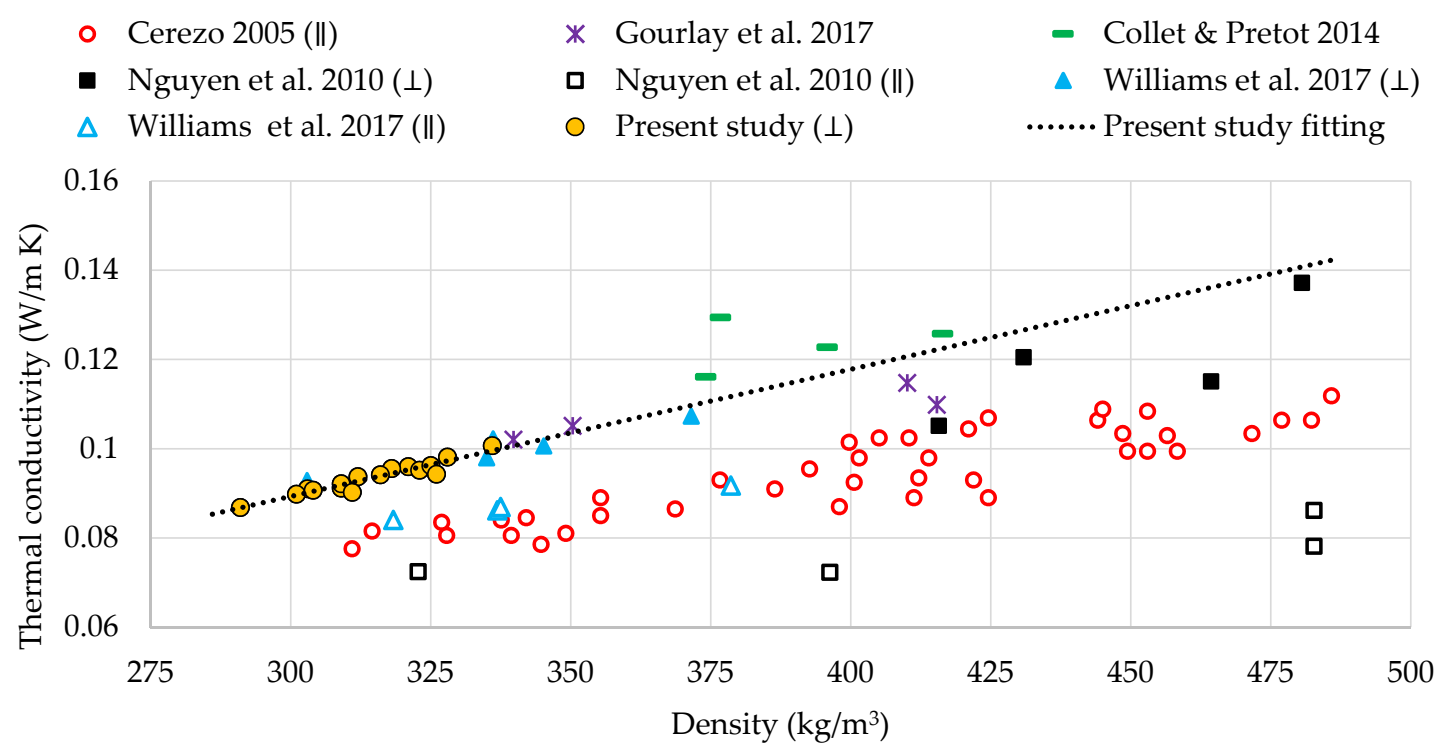

Figure 4. Thermal conductivity comparison with other studies.

\subsection{Moisture Buffering Results}

Figure 5 presents a comparison of moisture buffer values (MBV) for each cycle's uptake and release phases until reaching the steady-state of three selected hempcrete samples, LMK50, LNHL50, and LCB10, with two initial moisture conditions, high and low. As shown for the high moisture initial condition, the MBV for the release phase starts with a higher value $\left(2.4-2.6 \mathrm{gm} / \mathrm{m}^{2} \mathrm{RH} \%\right.$ ) than that of the uptake phase (1.3-1.7 gm/ $\left.\mathrm{m}^{2} \mathrm{RH} \%\right)$. The hempcrete samples tend to lose the high moisture content obtained from the initial condition more than absorbing more moisture. However, after the initial moisture content reduces, the MBV for the uptake phase increases again. In contrast, the MBV for the release phase slightly decreases until both reach steady-state starting from the fourth cycle with less than $5 \%$ difference between MBV for uptake and release. For the low moisture initial condition case, the MBV for the uptake phase starts with a higher value $\left(3-4 \mathrm{gm} / \mathrm{m}^{2} \mathrm{RH} \%\right)$ than that of the release phase $\left(2-2.8 \mathrm{gm} / \mathrm{m}^{2} \mathrm{RH} \%\right)$. The hempcrete samples are capable of absorbing more moisture due to the low initial moisture content. The MBV for the uptake phase decreases again, and the MBV for the release phase slightly increases until both reach steady-state starting from the fourth cycle, with a difference of less than 5\% between MBV for uptake and release.

The three design mixes express different moisture buffering behaviors. For example, the LNHL50 with high initial moisture condition starts with $14 \%$ and $26 \%$ higher MBV as compared with LCB10 and LMK50, in the uptake phase and $2.6 \%$ and $13.8 \%$ higher in the release phase, respectively. Furthermore, the starting MBV values of the LCB10 with low initial conditions are $11.2 \%$ and $39 \%$ higher than those of the LNHL50 and LMK50 counterparts in the uptake phase. Similarly, in the release phase, the starting MBV values of the LCB10 are $14 \%$ and $42 \%$ higher than those of LNHL50 and LMK50, respectively. Moreover, the LCB10 shows approximately 1.2\% higher steady-state MBV than LNHL50, and $18 \%$ higher than LMK50.

Figure 6 shows the percentage mass change relative to the initial mass during the test for the selected samples subjected to the humidity cycles. As presented, all specimens show the same mass change profile with a gradual increase or decrease, depending on the initial condition, until they reach a steady-state starting from the fourth cycle. Moreover, the LCB10 sample has the highest mass gain and release in the uptake and release portions of the cycle, respectively, regardless of the initial condition. The LNHL50 and LMK50 samples show comparable rates of mass gain and release.

Figure 7 presents the average steady-state MBV values of the hempcrete samples. The average steady-state MBV for all hempcrete samples of $2.78 \mathrm{gm} / \mathrm{m}^{2} \mathrm{RH} \%$, with a standard deviation of $0.24 \mathrm{gm} / \mathrm{m}^{2} \mathrm{RH} \%$ (8.6\%), falls in the range reported in the literature. For example, Collet et al. (2013) 
reported an MBV of $2.14 \mathrm{gm} / \mathrm{m}^{2} \% \mathrm{RH}$, with a binder to hemp ratio of 2:1, and density of $430 \mathrm{~kg} / \mathrm{m}^{3}$ [14], while Latif et al. (2015) reported an MBV of $3.47 \mathrm{gm} / \mathrm{m}^{2} \% \mathrm{RH}$ with a binder to hemp ratio of 1.2:1, and density of $290 \mathrm{~kg} / \mathrm{m}^{3}$ [13]. The findings suggest that the initial moisture content condition does not significantly affect the final steady-state average MBV for each design mix (i.e., the difference is less than $1 \%)$.

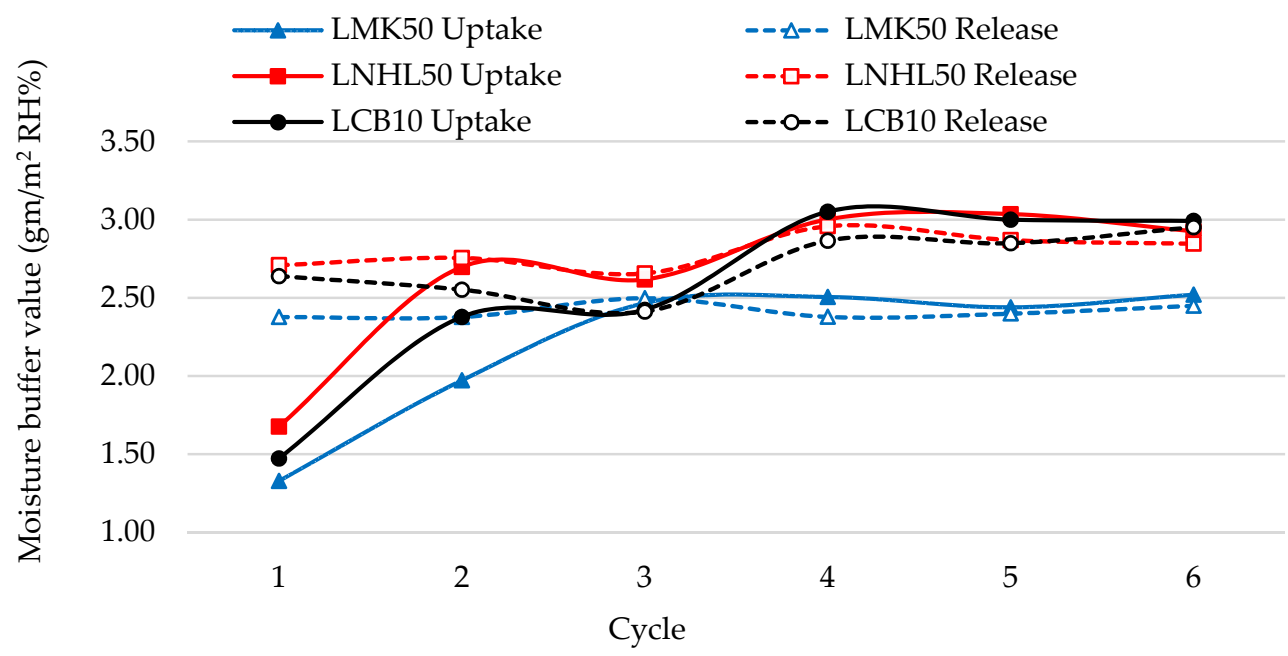

(a)

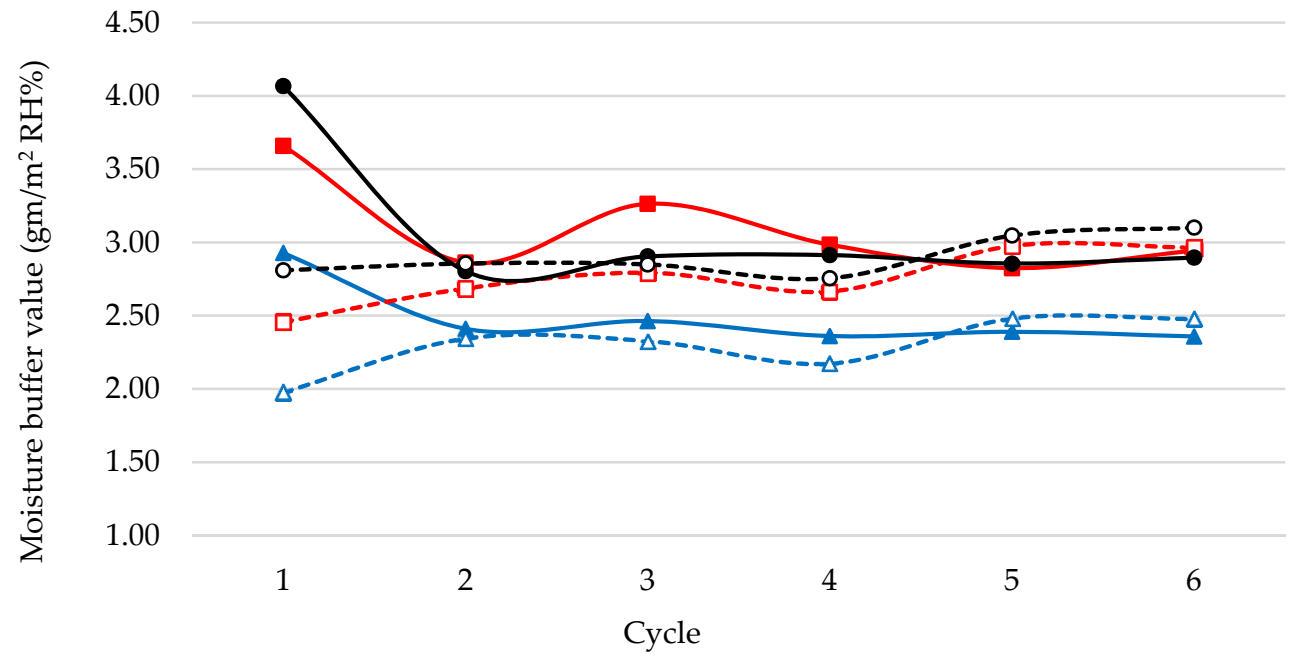

(b)

Figure 5. Moisture buffer value with cycles with different initial conditions. (a) High moisture content initial condition; (b) Low moisture content initial condition. 


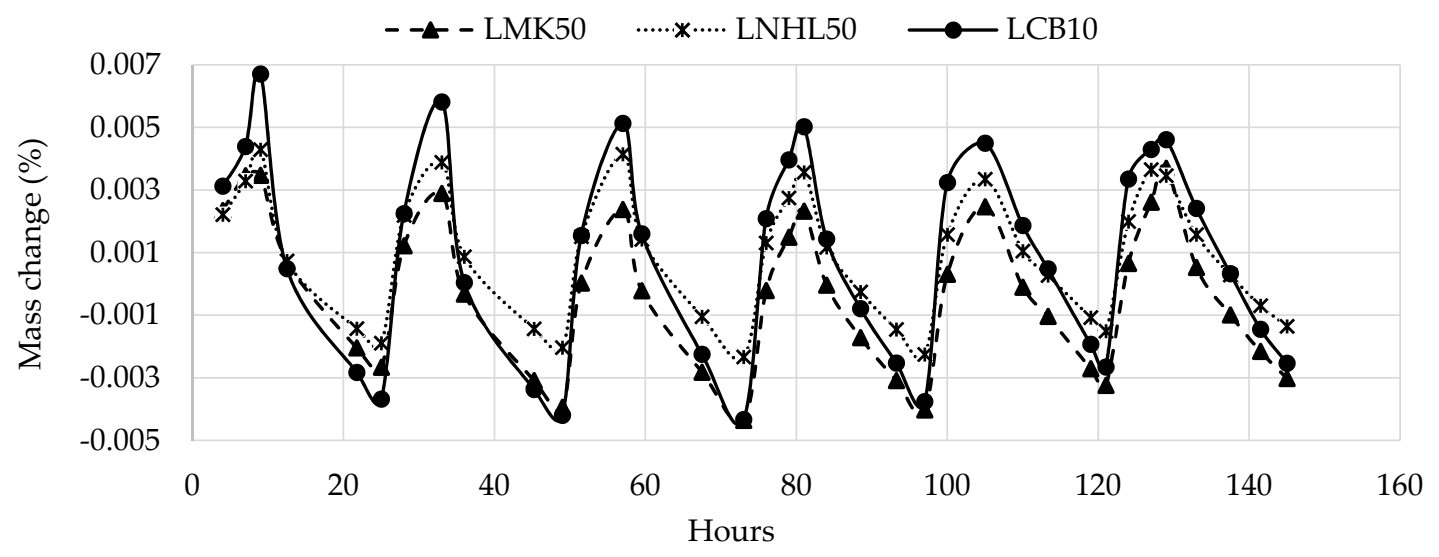

(a)

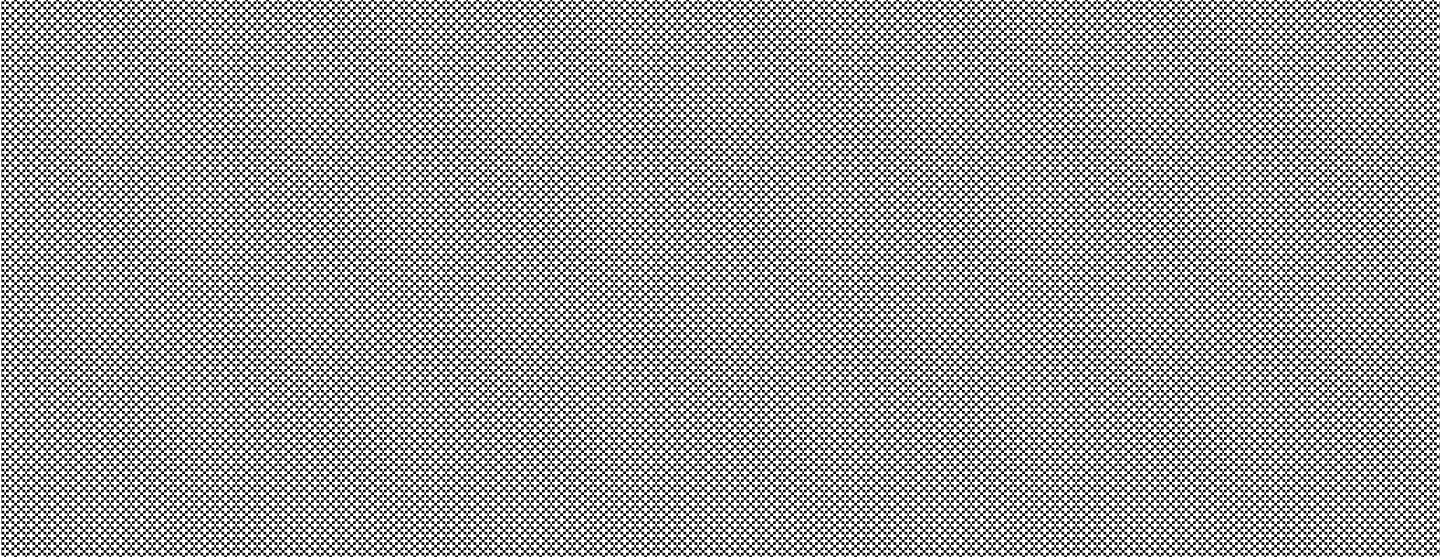

(b)

Figure 6. Typical steady cycle with different boundary conditions. (a) High moisture content initial condition; (b) Low moisture content initial condition.

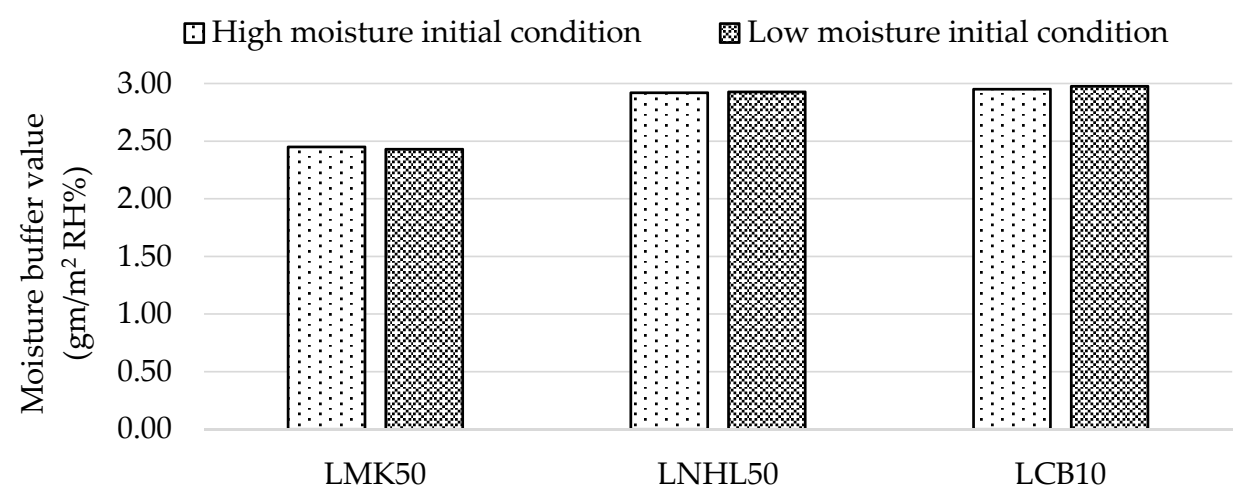

Figure 7. Average steady-state moisture buffer value (MBV).

\section{Discussion}

The overall findings suggest that hempcrete mixes with 1:1 binder to hemp hurd ratio and $300-400 \mathrm{~kg} / \mathrm{m}^{3}$ density have mechanical and hygrothermal properties suitable for infill wall applications. For instance, the compressive strengths ranging from 0.09 to $0.57 \mathrm{MPa}$ are comparable to the values reported by the previous studies that used higher binder to hurd ratios (i.e., 2:1 and 2.25:1) [18,26]. Similarly, thermal conductivity and specific heat capacity values in the range of $0.087-0.10 \mathrm{~W} / \mathrm{m} \mathrm{K}$ and 1250-1557 J/kg K correspond to the values reported by the studies that developed hempcrete 
samples with similar densities $[5,10,26,46]$. Furthermore, the average steady-state moisture buffer value (MBV) for all hempcrete samples of $2.78 \mathrm{gm} / \mathrm{m}^{2} \mathrm{RH}$ indicates excellent moisture storage capabilities. The splitting tensile strength ranging from 0.0101 to $0.0348 \mathrm{MPa}$ is the only measured parameter that is comparatively lower than the previous studies' results. The likely reasons are the lower density range and the binder to this study's hemp hurd ratio. In addition, hempcrete composites made from hydrated lime have significantly lower flexural strength than composites made from commercial composites [4,49].

The novel hempcrete mixes with hydrated lime and crushed brick (LCB) show comparable compressive and tensile strength to other design mixes, with the advantage of being composed of recycled material. For instance, the hempcrete samples with 10\% crushed brick have compressive strengths higher than the average of all the design mixes. Additionally, the LCB samples have the lowest thermal conductivity considering their density and the highest average moisture buffer values for high and low initial moisture contents, which are approximately $18 \%$ higher than metakaolin formulas and comparable to design mixes with hydraulic lime.

The hempcrete's density is a vital design parameter due to its significant effects on the material's mechanical and thermal properties. For instance, on the one hand, hempcrete samples of approximately $340 \mathrm{~kg} / \mathrm{m}^{3}$ and above have $45 \%-75 \%$ higher compressive and tensile strengths than those with lower density (i.e., $300-330 \mathrm{~kg} / \mathrm{m}^{3}$ ). On the other hand, the low-density hempcrete samples (i.e., $290-310 \mathrm{~kg} / \mathrm{m}^{3}$ ) have $8-13 \%$ lower thermal conductivity than those in the range of $320-336 \mathrm{~kg} / \mathrm{m}^{3}$. Furthermore, as illustrated in Figure 8, an increase in thermal conductivity with a rise of compressive strength tends to be higher in the low than the upper range of compressive strength values. These findings indicate that the specific application should determine the density of the hempcrete biocomposites. The results also show that similar to previous studies $[9,26]$, there is a strong positive linear correlation $\left(R^{2}=0.91\right)$ between the dry and wet samples' conductivities and their densities. The relationship between compressive strength and density is weaker and increases over time from 0.36 at 28 days to 0.77 at 90 days.

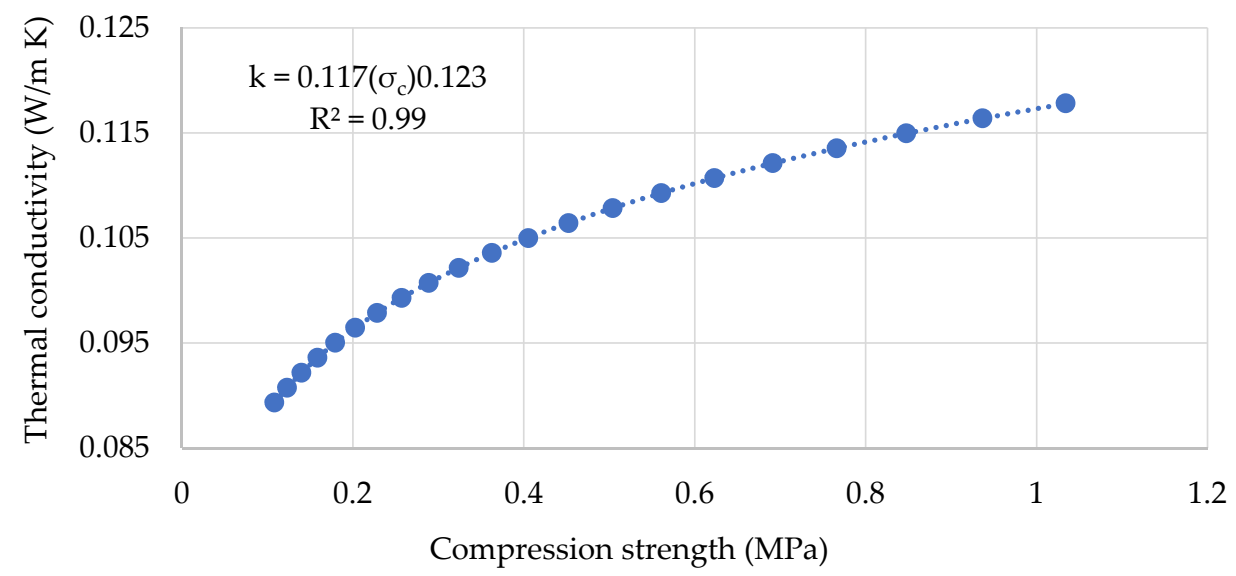

Figure 8. Thermal conductivity as a function of compressive strength.

The results also indicate that binder mix design and water content impact the prepared hempcrete samples' thermal and mechanical properties. For example, an increase in the percent share of metakaolin and crushed brick reduces thermal conductivity and specific heat capacity. In contrast, increasing the hydraulic lime percentage increases the conductivity and specific heat capacity. In addition, an increase in the percent share of pozzolans above a certain amount can harm the mechanical properties of hempcrete, particularly when combined with reduced water content (i.e., 2.5:1 water to hemp ratio). This hindering effect is most significant when metakaolin is increased above $50 \%$, followed by crushed brick above $10 \%$. 


\section{Conclusions and Future Research}

Despite excellent hemp-lime composites' hygrothermal properties, their utilization in the construction industry remains low due to the high variability and lack of formulas with widely available ingredients. The use of innovative binders and a better understanding of the material's performance are indispensable steps for addressing hempcrete's underutilization. This is the first research study that applies recycled crushed brick as a pozzolan in hempcrete mixes to increase their availability and performance while reducing their environmental impact. Another contribution to the body of knowledge is the comprehensive mechanical and hygrothermal characterization of hemp-lime composites with different binder mix designs. Consequently, this study provides valuable information about insulating hemp-lime composites' critical performance required for material characterization that is likely to interest audiences, in academia and industry, who are focused on sustainable low-carbon composite building materials. The main conclusions of this study that point to the need for future work and investigation are as follows:

- The thermal and mechanical properties of hempcrete depend on its density. Hence, the large-scale utilization of hemp-lime composites in the construction industry requires the use of manufactured blocks, wall panels, or spraying techniques to enable the construction of consistent code complying envelope systems. Therefore, future work should focus on the processing methods for optimizing and standardization of hempcrete design mixes for different envelope applications and installations. Furthermore, future work should increase the number of tested samples for each design mix to ensure consistency.

- The higher content of hemp hurd combined with an application-orientated level and direction of compaction can lead to the development of products suitable for infill wall utilizations. A follow-up study should investigate mechanical properties in the perpendicular and thermal behavior in the parallel direction of hempcrete formulas with a 1:1 binder to hemp hurd ratio and $300-400 \mathrm{~kg} / \mathrm{m}^{3}$ density. Further research should also optimize compaction levels and orientations for infill wall installations of hemp-lime composites using blocks or wall panels.

- Although all the developed design mixes have mechanical and hygrothermal properties suitable for infill wall applications, in small amounts, recycled crushed brick is an excellent alternative to conventional pozzolans for creating more environmentally-friendly hempcrete composites. For example, the hempcrete samples with $10 \%$ crushed brick have the lowest thermal conductivity considering their density and the highest moisture buffer capacity. Furthermore, the new hydrated lime and crushed brick formulas have comparable mechanical properties to metakaolin and hydraulic lime formulas. Future research should combine and optimize the use of the investigated lime mortars and pozzolans in hemp-lime mixes. A follow-up study should also explore other locally available materials that can improve hemp-lime composites' performance and affordability while reducing their environmental impact.

- The water content is an essential design parameter due to its significant impact on the hempcrete samples' mechanical and thermal properties. This study indicates that a smaller amount of water (i.e., $\leq 2.5 \mathrm{~kg}$ ) leads to some specimens' inferior mechanical properties due to incomplete hydration caused by the high suction ability of the hemp hurd. A follow-up study should optimize water content for different infill wall application approaches such as blocks, wall panels, or spray-in. Further research should also develop a hemp pretreatment process and investigate water retainers' application to balance the high suction of the hurd and improve mechanical behavior and durability of hemp-lime composites. Future research should also investigate hemp-lime composites' durability and decay under different environmental conditions.

Author Contributions: Conceptualization, Y.A. and M.C.; methodology, Y.A., M.A.K., A.K., M.I.A., and M.K.; software, Y.A.; validation, Y.A., M.A.K., A.K.; M.I.A., and M.K.; formal analysis, Y.A., M.A.K., A.K., M.I.A., and M.K.; investigation, Y.A., M.A.K., A.K.; M.I.A., and M.K.; resources M.K.; data curation, Y.A. and M.K.; writing—original draft preparation Y.A.; writing—review and editing, M.K., M.A.K., A.K., and M.I.A.; visualization, 
Y.A.; supervision M.K.; project administration, M.K.; funding acquisition, M.K. All authors have read and agreed to the published version of the manuscript.

Funding: This research was funded by the Natural Sciences and Engineering Research Council (NSERC) Discovery Grant, grant number RGPIN-05481.

Acknowledgments: The authors would like to acknowledge the in-kind contributions of "Plains Hemp" and "WhiteMud Resources".

Conflicts of Interest: The authors declare no conflict of interest.

\section{References}

1. Stanwix, W.; Sparrow, A. The Hempcrete Book: Designing and Building with Hemp-Lime; Green Books; UK Hempcrete: Matlock, UK, 2014.

2. Pochwala, S.; Makiola, D.; Anweiler, S.; Bohm, M. The Heat Conductivity Properties of Hemp-Lime Composite Material Used in Single-Family Buildings. Materials 2020, 13, 1011. [CrossRef]

3. Magwood, C. Essential Hempcrete Construction: The Complete Step-by-Step Guide; New Society Publishers: Gabriola Island, BC, Canada, 2016.

4. Jami, T.; Karade, S.R.; Singh, L.P. A review of the properties of hemp concrete for green building applications. J. Clean. Prod. 2019, 239, 117852. [CrossRef]

5. Evrard, A. Transient Hygrothermal Behavior of Lime-Hemp Materials. Ph.D. Thesis, Universite Catholique De Louvain, Ottignies-Louvain-la-Neuve, Belgium, 2008.

6. Manh, D.T. Contribution to the Development of Precast Hempcrete Using Innovative Pozzolanic Binder. Ph.D. Thesis, Université Toulouse III-Paul Sabatier, Toulouse, France, 2014.

7. Ntimugura, F.; Vinai, R.; Harper, A.; Walker, P. Mechanical, thermal, hygroscopic and acoustic properties of bio-aggregates-Lime and alkali-Activated insulating composite materials: A review of current status and prospects for miscanthus as an innovative resource in the South West of England. Sustain. Mater. Technol. 2020, 26, e00211. [CrossRef]

8. De Bruijn, P.; Johansson, P. Moisture fixation and thermal properties of lime-hemp concrete. Constr. Build. Mater. 2013, 47, 1235-1242. [CrossRef]

9. Cérézo, V. Propriétés Mécaniques, Thermiques et Acoustiques d'un Matériau à Base de Particules Végétales: Approche Expérimentale et Modélisation Théorique; Le grade de docteur L'Institut National des Sciences Appliquées de Lyon: Lyon, France, 2005.

10. Walker, R.; Pavía, S. Moisture transfer and thermal properties of hemp-lime concretes. Constr. Build. Mater. 2014, 64, 270-276. [CrossRef]

11. Arnaud, L.; Boyeux, B.; Hustache, Y. Hemp and the Construction Industry; Hemp: Industrial Production and Uses; CABI: Wallingford, UK, 2013; pp. 239-259.

12. Lawrence, M.; Fodde, E.; Paine, K.; Walker, P. Hygrothermal Performance of an Experimental Hemp-Lime Building. Key Eng. Mater. 2012, 517, 413-421. [CrossRef]

13. Latif, E.; Lawrence, M.; Shea, A.; Walker, P. Moisture buffer potential of experimental wall assemblies incorporating formulated hemp-lime. Build. Environ. 2015, 93, 199-209. [CrossRef]

14. Collet, F.; Chamoin, J.; Pretot, S.; Lanos, C. Comparison of the hygric behaviour of three hemp concretes. Energy Build. 2013, 62, 294-303. [CrossRef]

15. Rahim, M.; Douzane, O.; Tran Le, A.D.; Langlet, T. Effect of moisture and temperature on thermal properties of three bio-based materials. Constr. Build. Mater. 2016, 111, 119-127. [CrossRef]

16. Yates, T. Final Report on the Construction of the Hemp House at Haverhill, Suffolk; Building Research Establishment: Watford, UK, 2002.

17. Abdellatef, Y.; Kavgic, M. Thermal, microstructural and numerical analysis of hempcrete-microencapsulated phase change material composites. Appl. Therm. Eng. 2020, 178, 115520. [CrossRef]

18. Elfordy, S.; Lucas, F.; Tancret, F.; Scudeller, Y.; Goudet, L. Mechanical and thermal properties of lime and hemp concrete ("hempcrete") manufactured by a projection process. Constr. Build. Mater. 2008, 22, 2116-2123. [CrossRef]

19. Barnat-Hunek, D.; Smarzewski, P.; Fic, S. Mechanical and Thermal Properties of Hemp-Lime Composites. Compos. Theory Pract. 2015, 15, 21-27. 
20. Nguyen, T.-T.; Picandet, V.; Amziane, S.; Baley, C. Influence of compactness and hemp hurd characteristics on the mechanical properties of lime and hemp concrete. Eur. J. Environ. Civ. Eng. 2009, 13, 1039-1050. [CrossRef]

21. Tronet, P.; Lecompte, T.; Picandet, V.; Baley, C. Study of lime hemp composite precasting by compaction of fresh mix-An instrumented die to measure friction and stress state. Powder Technol. 2014, 258, 285-296. [CrossRef]

22. Walker, R.; Pavía, S. Behaviour and Properties of Lime-Pozzolan Pastes. In Proceedings of the 8th International Masonry Conference, Dresden, Germany, 4-7 July 2010.

23. Walker, R.; Pavia, S.; Mitchell, R. Mechanical properties and durability of hemp-lime concretes. Constr. Build. Mater. 2014, 61, 340-348. [CrossRef]

24. Sheridan, J.; Sonebi, M.; Taylor, S.; Amziane, S. Effect of linseed oil and metakaolin on the mechanical, thermal and transport properties of hemp-lime concrete. In Proceedings of the 2nd International Conference on Bio-Based Building Materials, Clermont Ferrand, France, 21-23 June 2017; pp. 125-133.

25. Silva, R.V.; De Brito, J.; Dhir, R.K. Properties and composition of recycled aggregates from construction and demolition waste suitable for concrete production. Constr. Build. Mater. 2014, 65, 201-217. [CrossRef]

26. Williams, J.; Lawrence, M.; Walker, P. The influence of the casting process on the internal structure and physical properties of hemp-lime. Mater. Struct. 2017, 50, 108. [CrossRef]

27. ASTM C136-06, Standard Test Method for Sieve Analysis of Fine and Coarse Aggregates; ASTM International: West Conshohocken, PA, USA, 2006.

28. ASTM C207-06, Standard Specification for Hydrated Lime for Masonry Purposes; ASTM International: West Conshohocken, PA, USA, 2006.

29. ASTM C618, Standard Specification for Coal Fly Ash and Raw or Calcined Natural Pozzolan for Use in Concrete; ASTM International: West Conshohocken, PA, USA, 2012.

30. ASTM C1707, Standard Specification for Pozzolanic Hydraulic Lime for Structural Purposes; ASTM International: West Conshohocken, PA, USA, 2009.

31. Nguyen, T.T. Contribution à l'étude de la Formulation et du Procédé de Fabrication d'éléments de Construction en Béton de Chanvre. Ph.D. Thesis, Université de Bretagne Sud, Morbihan, France, 2010.

32. Pinkos, J. The Effectiveness of Hempcrete as an Infill Insulation in the Prairies Compared to a Standard Building Based on Power Consumption. Master's Thesis, University of Manitoba, Winnipeg, MB, Canada, 2014.

33. Collet, F.; Pretot, S. Thermal conductivity of hemp concretes: Variation with formulation, density and water content. Constr. Build. Mater. 2014, 65, 612-619. [CrossRef]

34. ASTM C39/C39M, Standard Test Method for Compressive Strength of Cylindrical Concrete Specimens; ASTM International: West Conshohocken, PA, USA, 2012.

35. ASTM C496/C496M-17, Standard Test Method for Splitting Tensile Strength of Cylindrical Concrete Specimens; ASTM International: West Conshohocken, PA, USA, 2017.

36. ASTM D4832-16e1, Standard Test Method for Preparation and Testing of Controlled Low Strength Material (CLSM) Test Cylinders; ASTM International: West Conshohocken, PA, USA, 2016.

37. ASTM C469/C469M-14, Standard Test Method for Static Modulus of Elasticity and Poisson's Ratio of Concrete in Compression; ASTM International: West Conshohocken, PA, USA, 2014.

38. ASTM C518-17, Standard Test Method for Steady-State Thermal Transmission Properties by Means of the Heat Flow Meter Apparatus; ASTM International: West Conshohocken, PA, USA, 2017.

39. ASTM C1784-14, Standard Test Method for Using a Heat Flow Meter Apparatus for Measuring Thermal Storage Properties of Phase Change Materials and Products; ASTM International: West Conshohocken, PA, USA, 2014.

40. NIST SRM 1450. Energy and Environment Division, NIST. Available online: https://www.nist.gov/energyandenvironment-division/nist-srm-1450 (accessed on 10 November 2018).

41. Tleoubaev, A.; Brzezinski, A. Thermal Diffusivity and Volumetric Specific Heat Measurements Using Heat Flow Meter Instruments. In Proceedings of the Thermal Conductivity 29/Thermal Expansion 17 Conference, Birmingham, Alabama, 24-27 June 2007.

42. Rode, C.; Peuhkuri, R.H.; Hansen, K.K.; Time, B.; Svennberg, K.; Arfvidsson, J.; Ojanen, T. NORDTEST Project on Moisture Buffer Value of Materials. In Proceedings of the AIVC 26th Conference: Ventilation in Relation to the Energy Performance of Buildings, Brussels, Belgium, 21-23 September 2005; pp. 47-52.

43. Ge, H.; Yang, X.; Fazio, P.; Rao, J. Influence of moisture load profiles on moisture buffering potential and moisture residuals of three groups of hygroscopic materials. Build. Environ. 2014, 81, 162-171. [CrossRef] 
44. Li, Y.; Fazio, P.; Rao, J. An investigation of moisture buffering performance of wood paneling at room level and its buffering effect on a test room. Build. Environ. 2012, 47, 205-216. [CrossRef]

45. Eires, R.; Nunes, J.P.; Fangueiro, R.; Jalali, S.; Camões, A. New Eco-Friendly Hybrid Composite Materials for Civil Construction. In Proceedings of the European Conference on Composite Materials Biarritz, Biarritz, France, 29 August-1 September 2006.

46. Tran Le, A.D.; Maalouf, C.; Mai, T.H.; Wurtz, E.; Collet, F. Transient hygrothermal behaviour of a hemp concrete building envelope. Energy Build. 2010, 42, 1797-1806. [CrossRef]

47. Evrard, A.; Herde, A.D. Bioclimatic envelopes made of lime and hemp concrete. In Proceedings of the CISBAT2005 Conference-Renewables in a Changing Climate-Innovation in Building Envelopes and Environmental Systems at Lausanne, Lausanne, Switzerland, 27-28 September 2005.

48. Nguyen, T.T.; Picandet, V.; Carre, P.; Lecompte, T.; Amziane, S.; Baley, C. Effect of compaction on mechanical and thermal properties of hemp concrete. Eur. J. Environ. Civ. Eng. 2010, 14, 545-560. [CrossRef]

49. Murphy, F.; Pavía, S.; Walker, R. An assessment of some physical properties of hemp-lime concrete. In Proceedings of the BCRI Bridge Infrastructure Concrete Research Ireland, Cork, Ireland, 2 September 2010; pp. 431-438.

Publisher's Note: MDPI stays neutral with regard to jurisdictional claims in published maps and institutional affiliations.

(C) 2020 by the authors. Licensee MDPI, Basel, Switzerland. This article is an open access article distributed under the terms and conditions of the Creative Commons Attribution (CC BY) license (http://creativecommons.org/licenses/by/4.0/). 